\title{
SISEA activities in Pasteur Institute in Nha Trang, Vietnam, during 2008-2009
}

\author{
Bui Trong Chien", Vien Quang Mai, Trinh Thi Xuan Mai, Nguyen Hai Nam, Đoan Thi thanh Thuy \\ From Institut Pasteur International Network Annual Scientific Meeting \\ Hong Kong. 22-23 November 2010
}

\begin{abstract}
Background
In recent years, the situation of dangerous infectious disease has developed more complex. Some emerging infectious diseases such as Severe Acute Respiratory Syndrome (SARS), avian influenza tend to globalization. In Central Vietnam, a lot of infectious diseases circulating every year caused serious consequences such as SARI, VE, DF/DHF, etc. For SARI, except influenza virus which has monitored, the other respiratory pathogens have not been concerned yet. It's difficult to detect some agents cause disease in regional and provincial laboratory. In order to respond the complex development of emerging diseases such as SARS, avian influenza, severe acute respiratory infection (SARI), viral encephalitis (VE) and Dengue fever/Dengue haemorrhagic fever, Pasteur Institute Network in Southeast Asia has implemented the project "Surveillance and Investigation of epidemic situation in South East Asia (SISEA)".
\end{abstract}

\section{Results}

A specific surveillance system for Severe Acute Respiratory Infection (SARI) was established in 02 sentinel hospitals in Bin Dinh province from January 2008 to December 2009. Patient's signature on written ICF had been required before the enrollment and samples (nasopharyngeal swabs) were analyzed by RT-PCR multiplex. There were 1,155 cases of SARI enrolled, with $47.2 \%$ testing positive for one of the 17 respiratory viruses included in our panel. Rhinvoirus (24\%) and respiratory syncitial virus (18\%) accounted for almost $50 \%$ of the positive samples. Adenovirus, human metapneumovirus and NL63 coronavirus were present in $5-6 \%$ of the samples, whereas other respiratory viruses showed lower incidence. Of note, only few samples tested positive for pandemic H1N1 influenza. In addition, we carried out a number of training and

Pasteur Institute of Nha Trang, Vietnam supervision sessions for the personnel of the sentinel hospitals, both in field epidemiology and molecular laboratory techniques.

\section{Conclusion}

This project is strengthening laboratory capability as well as epidemiological surveillance system to enable rapid diagnosis and prevention of dangerous epidemics, thus helping to contain their spread in the region. This is really necessary and responds to current practical needs in Central Vietnam.

Published: 10 January 2011

doi:10.1186/1753-6561-5-S1-P117

Cite this article as: Chien et al.: SISEA activities in Pasteur Institute in Nha Trang, Vietnam, during 2008-2009. BMC Proceedings 2011 5(Suppl 1): P117.
Submit your next manuscript to BioMed Central and take full advantage of:

- Convenient online submission

- Thorough peer review

- No space constraints or color figure charges

- Immediate publication on acceptance

- Inclusion in PubMed, CAS, Scopus and Google Scholar

- Research which is freely available for redistribution
() Biomed Central

\section{Biomed Central}

(C) 2011 Chien et al; licensee BioMed Central Ltd. This is an open access article distributed under the terms of the Creative Commons Attribution License (http://creativecommons.org/licenses/by/2.0), which permits unrestricted use, distribution, and reproduction in any medium, provided the original work is properly cited. 